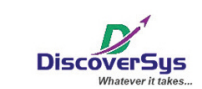

Published by DiscoverSys

\section{Sindroma emboli lemak pada kasus trauma orthopedi: sebuah tinjauan pustaka}

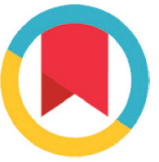

CrossMark

\author{
Angga Dharmayuda ${ }^{1 *}$, Anak Agung Ngurah Ronny Kesuma², Komang Mahendra Laksana²
}

\title{
ABSTRACT
}

Fat embolism (FE) is defined as fat embolism circulating in the bloodstream, with or without symptoms. Fat embolism syndrome (FES) is a circulatory fat embolism which is a secondary complication and causes specific clinical manifestations in the lungs, brain, skin. This incident is often found in orthopedic trauma, especially in

long bone trauma, pelvis, and multiple trauma. In non-traumatic cases, such as hip or knee arthroplasty, FES may also be present. Gurd and Wilson's current criteria can help guide the diagnosis, but at this time there are no standardized diagnostic tests. There is no definitive therapy for FES and only supportive therapy.

Keywords: fat embolism, syndrome, orthopedics, trauma

Cite This Article: Dharmayuda, A., Kesuma, A.A.N.R., Laksana, K.M. 2020. Sindroma emboli lemak pada kasus trauma orthopedi: sebuah tinjauan pustaka. Intisari Sains Medis 11 (3): 1005-1008. D0I: 10.15562/ism.v11i3.841

\section{ABSTRAK}

Emboli lemak (FE) didefinisikan sebagai emboli lemak yang beredar di aliran darah, dengan atau tanpa gejala. Fat Embolism Syndrome (FES) adalah emboli lemak peredaran darah yang merupakan komplikasi sekunder dan menyebabkan manifestasi klinis spesifik di paru-paru, otak, kulit. Kejadian ini sering ditemukan pada trauma ortopedi, terutama pada trauma tulang panjang, trauma panggul, dan trauma multipel. Dalam kasus non-traumatis, seperti artroplasti pinggul atau lutut, FES juga mungkin dapat ditemukan. Kriteria Gurd dan Wilson saat ini dapat membantu memandu diagnosis, tetapi saat ini belum ada tes diagnostik standar. Tidak ada terapi definitif untuk FES dan hanya terapi suportif.

Kata kunci: emboli lemak, sindrom emboli lemak, ortopaedi, trauma

Sitasi Artikel ini: Dharmayuda, A., Kesuma, A.A.N.R., Laksana, K.M. 2020. Sindroma emboli lemak pada kasus trauma orthopedi: sebuah tinjauan pustaka. Intisari Sains Medis 11 (3): 1005-1008. D0I: 10.15562/ism.v11i3.841

'Fakultas Kedokteran, Universitas Udayana, Bali-Indonesia 2Departemen Ortopedi dan Traumatologi, Rumah Sakit Umum Daerah Wangaya, Bali-Indonesia

*Korespondensi: Angga Dharmayuda Fakultas Kedokteran, Universitas Udayana, Bali-Indonesia; dharmayudaangga@gmail.com
Diterima: $15-10-2020$

Disetujui: 20-10-2020

Diterbitkan: 22-10-2020

\section{PENDAHULUAN}

Meskipun kasus pertama fat embolism syndrome (FES) dijelaskan lebih dari 150 tahun lalu, etiologinya masih relatif belum jelas. Maka dari itu, penegakan diagnosis FES masih menjadi hal yang cukup menantang untuk dokter orthopaedi. Istilah Fat Embolism (FE) mengacu pada adanya gumpalan lemak yang memasuki sirkulasi perifer (seringkali tanpa gejala). Sebaliknya, FES merupakan komplikasi dari FE, seringkali mengakibatkan tanda dan gejala klinis pernapasan dan neurologis yang mengancam jiwa. Patofisiologi FES sebagian besar masih belum diketahui, meskipun telah dijelaskan terutama pada pasien dengan fraktur tulang panjang akibat trauma tumpul, di mana lemak memasuki sirkulasi perifer sebagai akibat dari fraktur tersebut atau setelah Tindakan operatif fiksasi. ${ }^{1}$

FES berpotensi memperparah morbiditas dan mortalitas pada pasien dengan kasus politrauma. Ahli orthopaedi sudah memperhatikan kondisi ini sejak kasus FES pertama dilaporkan pada tahun 1873 yang disebabkan oleh fraktur femoral. ${ }^{2}$ Namun, pada abad 20 dikenalkannya gagasan stabilisasi fraktur tulang panjang sebagai pencegahan terjadinya FES. Waktu dilakukannya tindakan fiksasi memiliki peran krusial dalam proses perkembangan FES. Sejumlah artikel mengkonfirmasi bahwa fiksasi dini pada fraktur tulang panjang dalam waktu 24 jam setelah cedera awal dikaitkan dengan penurunan FES hingga 5 kali lipat dibandingkan dengan penundaan tindakan.

\section{DEFINISI}

Embolisi Lemak (FE) dapat diartikan sebagai adanya gumpalan lemak yang terdapat pada sistem peredaran darah dengan atau tanpa gejala klinis. ${ }^{3,4}$ FE ini paling sering ditemukan pada daerah yang 
terdapat banyak mirkovaskular, contohnya pada paru-paru (pulmonary FE) dan otak (cerebral $F E){ }^{3}$ Fat embolism syndrome (FES) merupakan manifestasi klinis emboli lemak pada sirkulasi yang ditandai dengan tanda dan gejala spesifik. ${ }^{4}$ FES didefinisikan juga sebagai karakteristik klinis yang mengakibatkan komplikasi sekunder FE dan tidak selalu ada pada pasien FE (Fukumoto \& Fukumoto, 2018).

\section{Epidemiologi}

FE cukup umum terjadi, lebih dari $90 \%$ pada pasien patah tulang Panjang, tetapi tidak semua kasus emboli lemak mengarah pada sindrom embolisi lemak. Kejadian pada FES sangat beragam, mulai dari $<1 \%$ dalam studi retrospectif dan 11\%-29\% dalam studi prospektif dan biasanya terdiri dari tiga serangkai gejala neurologis, paru, dan kulit. ${ }^{4}$

FES biasanya terjadi setelah trauma ortopaedi seperti patah pada tulang panjang, pelvis atau fraktur multipel. Akan tetapi, dapat juga ditemukan dalam kondisi non-traumatis seperti artoplasti pinggul atau lutut, luka bakar, pankreatitis, liposuction dan transplantasi sumsum tulang. ${ }^{4}$ Dapat diperkirakan bahwa 0,78\% kejadian FE terjadi pada pasien fraktur femur, $0,15 \%$ pada pasien fraktur tibial and $2.4 \%$ pada multipel fraktur. Secara keseluruhan insiden FE pada pasien patah tulang panjang sekitar $0,9 \%{ }^{5}$ Semua pasien yang mengalami FES membutuhkan pengangan secara intensif dan penanganan utama. ${ }^{4}$

FES dianggap sebagai komplikasi trauma yang mematikan tetapi manajemen waktu dapat membantu memberikan hasil yang lebih baik. Fiksasi dan immobilisasi dini pada tulang Panjang setelah fraktur yang signifikan dapat menekan FES dibandingkan dengan fiksasi yang terlambat. Fiksasi dini pada fraktur tulang Panjang juga sangat dianjurkan dilakukan dalam kurun waktu 24 jam. ${ }^{5}$ Menurut studi Aggarwal dkk. ${ }^{4}$ FES dapat tetap muncul setelah fiksasi fraktur. Maka dari itu, pasien patah tulang panjang, meski pasca operasi harus dirawat dengan kewaspadaan yang ketat dan memperhatikan adanya tanda-tanda hipoksia atau perubahan sensorium kemudian meningkatkan kecurigaan FES yang mewajibkan penanganan ruang intensif dini.

\section{Etiologi}

Saat ini eiologi FES relatifbelum diketahui meskipun kasus pertama sudah dideskripsikan lebih dari 150 tahun lalu. ${ }^{1}$ Pada kondisi tertentu yang sudah ada, bisa juga berkontribusi pada perkembangan FES. Pasien dengan kondisi bawaan, seperti Duchenne muacular dystrophy, memiliki resiko yang lebih tinggi untuk efek FES pada kasus trauma. Pasien dengen penyakit sickle cell mengalami peningkatan kejadian FES nontraumatis dikarenakan nekrosis sumsum tulang, sebesar $57 \%$ dalam 1 penelitian yang dilakukan dengan otopsi. ${ }^{3}$

\section{Patofisiologi}

Meskipun mekanisme yang tepat dalam FES tidak diketahui, komponen mekanikal dan biokemikal dapat berkontribusi terhadap patologi dan fisikal manifestasi dari FES. ${ }^{3}$

Teori mekanik menjelaskan bahwa kekuatan mekanis dari luar seperti cedera traumatis atau operasi invasive menyebabkan FES dari sumsum tulang atau jaringan adiposa memasuki sirkulasi vena. Sel-sel lemak ini mennjukkan sifat inflamasi dan trombotik yang dapat menghasilkan agregasi platelet dan terbentuknya fibrin saat beredar melalu vena. Kemudian dapat memasuki sistem pernafasan dan menumpuk pada tepi kapiler pulmonal paruparu, menyebabkan distress pernafasan dari pendarahan intrerstitial dan pembengkakan, kolaps alveolar, dan vasokonstriksi sekunder pada defisiensi oksigen. Gejala non-pulmonal, pateki, dan perubahan neurologis seperti pusing, diduga timbul dari sel lemak yang masuk pada sistem arterial melalui paten foramen ovale atau tepi kapiler pulmonal. ${ }^{3}$

Teori biokemikal menduga bahwa hilangnya lemak dari sumsum tulang pada fraktur tulang panjang melalui lipolisis, membentuk gliserol dan racun asam lemak bebas, menyebabkan edema pulmonal dan pendarahan. Pelepasan dari asam lemak bebas (FFAs) dalam sirkulasi juga merangsang pelepasan mediator inflamasi, seperti c-reaktif protein yang menyebabkan agegrasi FFA dan gumpalan lemak. Ini menyebabkan distres sindrom pernapasan akut (ARDS), disfungsi kontraktilitas jantung dan meningkatnya plasma konsentrasi lipase dan juga dapat memicu disfungsi dan gagal multiorgan. Secara khusus, di paru-paru, kerusakan karna FFAs langsung menyerang sel edotelial pulmonal, menyebabkan pembengkakan alveolar dan kemungkinan pendarahan. Lebih jauh lagi, kerusakan ini memicu aktifnya proinflamasi kaskade sitokin yang mampu menyebabkan vaskulitis, pneumonitis, dan hipoksia, dan memungkinkan terjadinya cidera paru akut (ALI), ARDS, dan gagal nafas. ${ }^{3}$

\section{Kriteria diagnosis}

Diagnosis FES terutama bersifat klinis. ${ }^{4}$ Presentasi klinis FES pada umumnya terjadi antara 24 hingga 72 jam setelah penanganan fiksasi awal, dengan satu studi menemukan rata-rata 48,5 jam setelah cedera. ${ }^{6}$ Gupta dkk. ${ }^{7}$ menggambarkan tiga rangkaian gejala klinis yang terkait dengan FES yaitu perubahan pernapasan, kelainan neurologis, dan bercak peteki. 
Karena diagnosis terkadang masih sulit ditentukan, Wilson mengusulkan kriteria diagnostik untuk emboli lemak. Kriteria tersebut meliputi 3 kriteria mayor, 5 minor, dan 2 laboratorium (ditunjukkan pada Tabel 1). Diagnosis sindrom emboli lemak dapat diasumsikan dengan adanya 1 kriteria mayor, 4 kriteria minor, dan makroglobulus lemak dalam urin. ${ }^{5}$

Tidak ada tes diagnostik tervalidasi standar untuk FES. Berbagai penulis telah mencoba untuk menentukan kriteria diagnostik seperti kriteria Gurd, Schonfeld dan Lindeque. ${ }^{5}$ Setelah penilaian tanda dan gejala klinis pasien, diagnosis didasarkan pada ketidak ikut sertaan dari keadaan patologi serius lainnya (seperti embolus paru, diseksi aorta, atau perdarahan intrakranial). ${ }^{1}$

\begin{tabular}{ll} 
Tabel 1. & $\begin{array}{c}\text { kriteria } \\
\text { berdasarkan Gurd dan Wilson }\end{array}$ \\
\hline Criteria & \multicolumn{1}{c}{ Description } \\
\hline Major & - Petechiae \\
& - Respiratory symptoms \\
& - Neurological symptoms \\
- & Tachycardia \\
Minor & - Pyrexia \\
& - Retinal changes (eye background \\
& with fat film/petechia) \\
& - Jaundice \\
& - Renal changes (anuria / oligouria) \\
& - Anemia \\
Laboratory & Thrombocytopenia \\
abnormalities & - Fat macroglobules in urine \\
& - Elevated erythrocyte sedimenta- \\
& tion rate
\end{tabular}

Tabel 2. Kriterian untuk FES dari Lindeque's

\begin{tabular}{l}
\hline Criteria \\
\hline - $\mathrm{PaO} 2<60 \mathrm{~mm} \mathrm{Hg}$ \\
- $\mathrm{PaCO} 2>55$ \\
- $\mathrm{pH}<7.3$ \\
- Increaratory rate $>35$ breaths per minute \\
\hline
\end{tabular}

Tabel 3. Sistem skoring FES dari Schonfeld's

\begin{tabular}{lc}
\hline \multicolumn{1}{c}{ Sign/Symptom } & Score \\
\hline Petechiae & 5 \\
Diffuse alveolar infi ltrates & 4 \\
Hypoxemia & 3 \\
Confusion & 1 \\
Fever $>38^{\circ} \mathrm{C}$ & 1 \\
Heart rate $>120$ beats $/ \mathrm{min}$ & 1 \\
Respiratory rate $>30 / \mathrm{min}$ & 1 \\
\hline
\end{tabular}

Note: Score $>5$ is diagnostic
Diagnosis FES dapat dibantu dengan penggunaan pemeriksaan laboratorium dan radiologi seperti rontgen dada, Computerized Tomography Pulmonary Angiogram (CTPA) dan Magnetic Resonance Imaging (MRI) ${ }^{1,5}$ Foto toraks menunjukkan infiltrasi yang tidak merata, atelektasis paru, dan/atau perdarahan alveolar. Identifikasi lobulus lemak dalam urin atau sputum mendukung diagnosis. ${ }^{5}$ CTPA dikembangkan pada 1990-an untuk mendiagnosis PE. Dalam hal diagnosis FE, CTPA dapat mendeteksi konsolidasi dependen yang menyebar dan opasitas groundglass, tetapi ini hanya menunjukkan FES daripada diagnosis definitif. Meskipun MRI dianggap sebagai pemindaian paling sensitif untuk mendeteksi FE otak, saat ini MRI tidak dapat digunakan untuk mendiagnosis FE paru. ${ }^{1}$

\section{Terapi}

Tidak ada pengobatan yang definitif untuk FES, dan tindakan supportif adalah managemen utama (terlihat pada Gambar 1). Menyadari dini, pengobatan supportif dan pencegahan adalah yang paling penting. ${ }^{8}$ Karena hipoksia adalah gejala FES yang paling umum, menyadari dini dapat dilakukan dengan memonitor semua pasien fraktur tulang panjang dengan pulse oxymetry untuk mengenali penurunan perlahan oksigenasi secara dini. ${ }^{9}$ Meskipun tidak ada pengobatan khusus untuk FES, sangat penting untuk memberikan perawatan suportif termasuk oksigenasi melalui kanula hidung, sungkup muka, atau ventilasi mekanis; penggunaan cairan intravena untuk menjaga volume vaskular; transfusi produk darah seperlunya; pemeliharaan nutrisi yang tepat; dan pencegahan trombosis vena dalam. Ketika FES didiagnosis lebih awal dan perawatan suportif dimulai dengan cepat, angka kematian biasanya $<10 \% .^{10}$

Fiksasi dini pada patah tulang panjang memainkan peran utama dalam mengurangi pelepasan gumpalan lemak, asam lemak, dan lipase ke sirkulasi dan mengakibatkan berkurangnya gejala dan komplikasi sindrom emboli lemak. Pengurangan gerakan tampaknya penting untuk meminimalkan embolisasi lemak. Meskipun mekanisme fiksasi dini yang tepat akan mengurangi emboli lemak masih sulit dipahami, mekanisme yang diusulkan dapat berupa pengurangan respons inflamasi untuk melepaskan lemak dan asam lemak dan akhirnya stabilisasi dinding kapiler. Baru-baru ini, teknik pembedahan dikembangkan untuk menargetkan mekanisme lain dari emboli lemak, terutama teori mekanis. Teknik bedah baru dikembangkan untuk mengurangi tekanan intraoseus yang meningkat melalui penggunaan kuku ureamed, rim tajam, atau kuku berlubang 


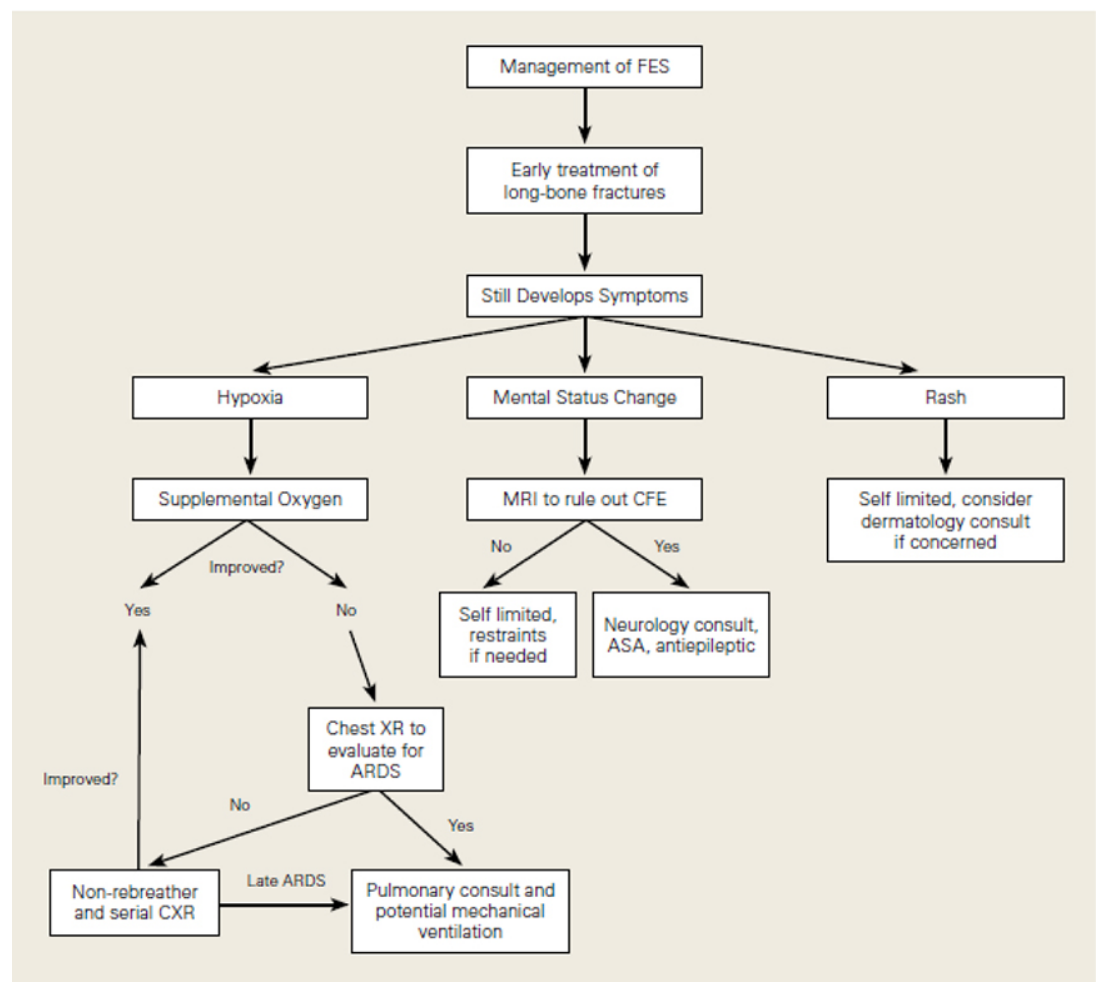

Gambar 1. Alogaritma penanganan sindroma emboli lemak. ${ }^{6}$ Singkatan: ARDS, acute respiratory distress syndrome; ASA, acetylsalicylic acid (aspirin); CFE, cerebral fat embolism; CXR, chest radiograph; FES, fat embolism syndrome; MRI, magnetic resonance imaging; XR, radiograph.

untuk memungkinkan semacam ventilasi ke rongga meduler. Meskipun belum ada konsensus yang tersedia mengenai pentingnya fiksasi awal fraktur tulang panjang, terbukti bahwa imobilisasi awal fraktur memiliki dampak menguntungkan yang signifikan dalam mengurangi sindrom emboli lemak. $^{5}$

\section{Prognosis}

Terlepas dari pengetahuan yang semakin berkembang tentang patofisiologi dan kemajuan dukungan sistem organ, mortalitas yang terkait dengan FES tetap antara 5 hingga $15 \% .{ }^{11}$ Sementara sebagian besar pasien meninggal karena gagal napas dan cedera terkait, morbiditas jangka panjang paling baik berkorelasi dengan defek neurologis sebagai akibat FES fulminan akut yang umumnya terlihat pada pasien trauma. Disfungsi kognitif yang persisten telah didokumentasikan dengan baik dan setiap kecurigaan gangguan intelektual selama pemulihan harus segera dilakukan pengujian neuropsikologis formal. ${ }^{12}$ Rehabilitasi kognitif dapat meningkatkan kehilangan memori, defisit perhatian, penilaian, dan kualitas hidup secara keseluruhan. ${ }^{11}$

\section{KONFLIK KEPENTINGAN}

Penulis menyatakan tidak terdapat konflik kepentingan terkait publikasi dari tinjauan pustaka ini.

\section{DAFTAR PUSTAKA}

1. Kirk A, Elliott J, Varma D, Kimmel LA. Fat embolism syndrome: Experience from an Australian trauma centre. International Journal of Orthopaedic and Trauma Nursing. 2020;36:100746.

2. Akoh CC, Schick C, Otero J, Karam M. Fat embolism syndrome after femur fracture fixation: a case report. Iowa Orthop J. 2014;34:55-62.

3. Fukumoto LE, Fukumoto KD. Fat Embolism Syndrome. Nursing Clinics of North America 2018;53(3):335-347.

4. Aggarwal R., Banerjee A, Soni K, dev Kumar A, Anjan T. Clinical characteristics and management of patients with fat embolism syndrome in level I Apex Trauma Centre. Chinese Journal of Traumatology. 2019;22:172e176.

5. Alqarni SAM, Aloraini LI, Al Habib MS, Alsulami AF, Alyssa AM, et al. Incidence of Fat Embolism after Long Fracture Fixation Operations: Review Article. The Egyptian Journal of Hospital Medicine. 2017;69(4):2361-2365

6. DeFroda SF, Klinge SA. Fat Embolism Syndrome With Cerebral Fat Embolism Associated With LongBone Fracture. The American Journal of Orthopedics. 2016;45(7):E155-E521.

7. Gupta B, D'souza N, Sawhney C, Farooque K, Kumar A, Agrawal P, Misra MC. Analyzing fat embolism syndrome in trauma patients at AIIMS Apex Trauma Center, New Delhi, India. J Emerg Trauma Shock. 2011;4(3):337-41.

8. Tzioupis CC, Giannoudis PV. Fat embolism syndrome: What have we learned over the years? Trauma. 2011;13(4):259-81.

9. Powers KA, Talbot LA. Fat embolism syndrome after femur fracture with intramedullary nailing: case report. Am J Crit Care. 2011;20(3):264-6.

10. Gupta A, Reilly CS. Fat embolism. Cont. Educ. Anaesth Crit Care Pain. 2007;7(5):148-151.

11. O’Donnell JM. Fat Embolism Syndrome. Surgical Intensive Care Medicine. 2001;1(1):385-95.

12. Gray A, Torrens L, White TO, et al. The cognitive effects of fat embolus syndrome following an isolated femoral shaft fracture: a case report. J Bone Joint Surg Am. 2007;89:10926.

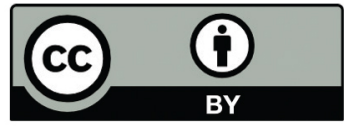

This work is licensed under a Creative Commons Attribution 